\title{
Research on the Application of Microblogging on Ideological and Political Education in Colleges and Universities
}

\author{
Kai Liang ${ }^{1}$, Wanru Zhou ${ }^{1}$ \\ ${ }^{1}$ Chengdu University of Information Technology, Chengdu, Sichuan, 610100
}

Keywords: Microblogging, Ideological and Political Education, College Education

\begin{abstract}
As a network of media, Microblogging has a huge impact on society. The characteristics of high-tech microblogging, fresh originality, and strong interactivity are in line with the characteristics of high quality, youthful activity, and strong participation of college students themselves, making microblogging more popular and popular among college students than other social groups, which also puts forward new requirements for the work of ideological and political education in colleges and universities, that is, to fully understand the social, political, and cultural influences brought about by Microblogging, and to truly find a good way to spread the ideological and political education through Microblogging.
\end{abstract}

\section{Introduction}

With the continuous advancement of network technology and the continuous updating of information exchange platforms, Microblogging has a place in the Internet platform with its mature technology and powerful functions, which has exerted a major influence on the thinking and behavior of university students. This impact not only brings opportunities for educational thinking in universities, but also brings challenges at the same time. As a new communication platform, Microblogging is convenient and fast in the dissemination of information. It can not only be displayed in textual form, but also can be displayed in the form of graphics, sounds, etc., which enables Microblogging to show its timeliness in the application process. The intriguing charm of infectiousness, its rich information and information also provide a large number of educational resources for ideological education work, making education content develop in a more vivid and fulfilling direction. At the same time, Microblogging also enables students to broaden their horizons, allowing them to self-learn and improve themselves during their spare time, so Microblogging has also established a new platform for ideological and political education. On this platform, educators can understand the student's dynamics by looking at the student's attention to the microblog situation, which is conducive to ideological education for students in a targeted manner. Students' questions can also be answered in time to achieve better teaching results.

\section{Microblogging meaning and characteristics}

The 140-character word limit of Microblogging has reduced the use threshold and satisfies people's fast-paced lifestyle expression needs. The combination with mobile phones has increased the convenience of publishing, which in turn has stimulated the desire of users to express, greatly increased the amount of information generated, and increased the timeliness of microblog information, such as the timely tracking and reporting of emergencies. Timeliness is shocking. The channels for Microblogging to publish information are also diversified, such as computers, mobile clients, SMS and MMS, WAB and WAP web pages, and IM software [1].

"Short and fine" is a distinctive feature of Microblogging that distinguishes it from other media. Fragmented comments can generally be used to understand related public opinion effects. Some scholars also believe that this fragmented information model will weaken people's deep thinking. From the content point of view, micro Bo's information presents a variety of features, graphic and textual, dynamic and static. It integrates text, pictures, audio and video. It is also a major factor in the rapid development and widespread popularity of Microblogging. 
Microblogging is based on a "follow-up" design pattern that differs from the rule that QQ, Renren, Facebook and other social networking sites need to add to each other as friends: "As long as the user is interested in another user, they can add" Focus on "," become its "fans." In this way, the information published by the "powdered" user can present a fission-like diffusion pattern by "forwarding", resulting in an increment of the geometric progression. This design pattern of Microblogging makes it highly open and free, and Microblogging users can freely choose the target of interest. Microblogging has changed the traditional media's dominant mode of dissemination and mass reception. "Since the media" has become a major feature of Microblogging, that is, each Microblogging user is an information publisher, forming a communication pattern of "everyone is the media." Microblogging users can communicate at any time and anywhere. Their short and short posts, ease of publishing, and variety of features enhance Microblogging's interactivity and improve communication efficiency. This is incomparable to traditional media [2].

\section{Microblogging's Influence on Ideological and Political Education in Colleges and Universities}

First, Microblogging has innovated the forms and methods of ideological and political education in universities. It profoundly affects the study and life of college students and can become a new type of carrier for ideological and political education in Colleges. Ideological and political educators can use microblogging to strengthen communication with students and enhance the interest of ideological and political education in Colleges. The ideological and political education through microblogging in daily life helps to better implement the infiltration principle of ideological and political education, and subtly influences the thinking and behavior of college students [3]. Second, Microblogging enhances the interaction between college ideological and political educators and students. Microblog can provide an interactive platform for the interaction of subject and object for ideological and political education, which helps to change the one-way pattern of subject-object communication in traditional ideological and political education in universities, and enables educators to understand and master students' thoughts directly, accurately and quickly. dynamic. Colliding with sparks of ideas in interactive exchanges and effectively improving the effectiveness of ideological and political education are conducive to constructing a "two-dimensional main body" model in which students are "core subjects" and teachers are "dominant subjects". Teachers can use this to keep abreast of the student's ideological dynamics and receive good feedback, which will help improve the flexibility and pertinence of ideological and political education in Colleges. At the same time, Microblogging's "back-to-face" design model makes it easier for students to express their inner real thoughts and narrow the distance between teachers and students. This helps teachers to guide students in their thinking and is conducive to ideological and political education in Colleges. Third, Microblogging has achieved the sharing of ideological and political education resources in universities. Microblogging is conducive to reducing the work cost of ideological and political education in universities. Its fissile diffusion model is conducive to the rapid dissemination of information released by ideological and political educators to more "fans" and the sharing and integration of resources.

"As a carrier of ideological and political education, we must satisfy the following basic conditions at the same time: First, we must carry information on the purpose, tasks, principles, and content of ideological and political education, and be easy for ideological and political educators to operate. Second, we must link the education subject and in a form of education object, the subject and object can interact with each other. The ideological and political education is not a unilateral education subject, but a process in which the education subject and the education object participate in and interact with each other. As a carrier of the comprehensive organization form of this process, The space for interaction between educators and educators must be provided."[3] It can be seen that microblogs have the basic conditions for becoming a carrier of ideological and political education. First, the content of Microblogging is short and accurate, can carry ideological and political education information, and is displayed through various forms such as texts, pictures, and videos, which is conducive to the development of lively ideological and political education. Moreover, 
college ideological and political education workers can operate it. Second, microblogs can be well connected with the subject and object of ideological and political education, providing an interactive platform for ideological and political education in Colleges, and becoming a "second class” to supplement classroom teaching.

\section{Introducing Microblogging into the Innovation and Application of Ideological and Political Education in Colleges and Universities}

First of all, we must have a positive attitude. The ideological and political educators in Colleges should profoundly realize that microblogs provide new opportunities for the bottleneck of the breakthrough in the development of ideological and political education in universities. They should actively study microblog functions and respond to the challenges brought about by microblogs, and introduce microblogs into Colleges. Ideological and political education and innovative applications. Secondly, we must have a proper orientation for the application of Microblogging in ideological and political education in Colleges. We must not ignore its influence or exaggerate its role as a new channel for ideological and political education in Colleges and do a good job in microblogs and traditions. The organic combination of the carrier of ideological and political education can better maximize its effectiveness. Once again, follow the laws of science. For Microblogging public opinion, "should not be blocked should be appropriate", reasonable dredge and guidance of microblog remarks, and effectively improve the practical effectiveness of ideological and political education in Colleges. Second, to treat both the symptoms and the problem-to improve the microblogging cultural quality of college students. Colleges should set up related courses to guide students to rationally view and rationally use microblogs, and encourage students to set up campus microblog associations to discuss related issues [4]. For "microblogging and control", we should focus on how to strengthen self-discipline and the rational use of microblogging to improve discernment, so as not to publish unscrupulous information, and consciously assume the public mission of purifying microblogging ecological environment and building a harmonious microblogging world.

The smooth implementation of ideological and political education in Colleges requires the entire school to work together. It is also necessary to establish a sound and educated college ideological and political education microblog cluster in order to enhance the systematic function of ideological and political education in Colleges. First, establish an official microblog platform for ideological and political education in universities and sing the main melody. In recent years, Microblogging has had a far-reaching impact on education, image-building, ideological and political education, and campus cultural activities in Colleges. The number of microblogging authentication accounts in universities has continuously increased, and its operating model is constantly innovating. The role of the official micro-blog in Colleges in the development of Colleges is becoming increasingly prominent, but there are not many special micro-blogs for ideological and political education in Colleges. In order to better introduce microblogging into college ideological and political education and apply it innovatively, Colleges should take the initiative to establish an official microblogging platform for ideological and political education in order to grasp the overall situation and sing the main melody. The official microblogging platform for ideological and political education in Colleges can be in charge of the relevant personnel of the school propaganda department, the school's moral education curriculum and information technology college, and divide the work to implement ideological and political education microblogging data search, content preparation and interactive work. Its content should closely follow the theme of the times, try to use the form of students in Colleges, in order to arouse the attention of more college students, timely update microblogging, interaction, and seriously solve student problems. The ideological and political education thematic microblogging in Colleges is conducive to schools to grasp the direction of public opinion, is the school's overall ideological and political education channel, plays an important role in guiding the direction of public opinion, plays the role of the "main campus melody", and dominates the school's mainstream values. And then maintain the stability of the school. 
Second, set up micro-blogs in various departments of Colleges to form a joint force for ideological and political education. The sub-microblogs of various departments include administrative departments and secondary colleges. They not only publish relevant information of the department, but also increase the content of ideological and political education. Each department's microblog should present different styles according to the characteristics of its department. For example, the school discipline commission department can publish microblogs that cultivate students' awareness of integrity, and the Academic Affairs Office can publish microblogs that motivate students to work hard and learn and use different functions from all sides. College students conduct a full range of ideological and political education [5]. Third, encourage ideological and political educators in universities to open microblogging and become students' "ideological leaders." University students can elect their "ideological leaders" on Microblogging; college ideological and political educators play a leading role in ideological and political education, and they should take the initiative to occupy Microblogging's position and work hard to become microblog students." "Thought leaders" to better play the role of "leader".

\section{Conclusion}

Explore new ways of ideological and political education in Colleges in the era of microblogging, carry out lively ideological and political education in universities, and open up new opportunities for ideological and political education in Colleges. This is for Lideshuren, the training of excellent socialist builders and successors. It is of great significance.

\section{References}

[1] Fan Wensheng, Li Xiaomeng. Nationwide/two sessions 0 see Microblogging [J]. News Outpost, 2010, (5).

[2] Lu Xinfu. Analysis of the characteristics of news dissemination in microblogging [J]. Present Media, 2010, (8).

[3] Zheng Yanlin, Li Luyi. A Preliminary Study on Microblogging Education [J]. China Education Informatization, 2010, (2).

[4] Hao Shengjie. How to Cope with Ideological and Political Education / The Challenge of Microblogging 0 [J]. Journal of Yangzhou University (Higher Education Research), 2010, (2).

[5] Kuang Daoyuan. Ideological and political work under the rise of Microblogging [J]. Research on Ideological and Political Work, 2010, (4). 